\title{
Effects of mitomycin $C$ on infiltration of polymorphonuclear leukocytes after epithelial scrape injury in the mouse cornea
}

\author{
Efeito da mitomicina $C$ na infiltração de leucócitos polimorfonucleares \\ após lesão epitelial em córnea de camundongo
}

\author{
Ana Cecília Souza Leão Escarião ${ }^{1}$ \\ Takayuki Nagasaki² \\ Jin Zhao ${ }^{3}$ \\ Richard Braunstein ${ }^{4}$
}

\begin{tabular}{l} 
ABSTRACT \\
\hline Purpose: To determine whether mitomycin C (MMC) alters appearance \\
and disappearance of polymorphonuclear leucocytes (PMN) in the \\
cornea stroma, using an epithelial scrape injury in eye mouse model. \\
Methods: Twenty-mice underwent mechanical epithelium debridement \\
in the central cornea using 20\% ethanol. After the scrape, the right eye \\
received 0.02\% MMC for one minute, while the left eye received phy- \\
siological saline. The animals were sacrificed on days 1,2,5, and 14 after \\
surgery, and corneal whole mounts were prepared for histology. PMN \\
distribution was analyzed in digitized microscope images. Cell division \\
in the cornea was determined by immunohistochemical detection of \\
bromodeoxyuridine (BrdU), which was injected intraperitoneally before \\
the mice were sacrificed. Results: Epithelial scrape injury triggered \\
infiltration of PMNs into the corneal stroma. An analysis of PMN \\
distribution revealed that there was no difference between eyes treated \\
with and without MMC at all time points. BrdU labeling showed that \\
0.02\% MMC for one minute blocked keratocyte proliferation completely. \\
Conclusion: MMC treatment regimen, which is common in clinical \\
practice, inhibits keratocyte proliferation during wound healing, but \\
when used at0.02\% for one minute, it does not affect PMN infiltrationinto \\
the corneal stroma, and subsequent movement toward the injury site, or \\
the disappearance of PMNs from the stroma, in the mouse epithelial \\
injury model.
\end{tabular}

Keywords: Mitomycin C/therapeutic use; Mitomycin C/administration \& dosage; Leukocyte; Cornea; Keratomileusis, laser in situ; Photorefractive keratectomy; Models, animal

Trabalho realizado no Department of Ophthalmology, Columbia University - New York (NY) - USA.

${ }^{1}$ Medical Doctor, Altino Ventura Foundation and Pernambuco Eye Hospital and ex-postdoctoral research fellow at Columbia University - New York (NY) - USA.

${ }^{2} \mathrm{PhD}$, Department of Ophthalmology, Columbia University - New York (NY) - USA.

${ }^{3} \mathrm{PhD}$, Department of Ophthalmology, Columbia University - New York (NY) - USA.

${ }^{4}$ Medical Doctor, Director of Refractive Surgery and Laser Vision Correction at Columbia University - New York (NY) - USA.

Endereço para Correspondência: Ana Cecília Souza Leão Escarião. Rua da Soledade, 170 - Recife (PE)

CEP 50070-040

E-mail: ana_cecilia09@yahoo.com

Recebido para publicação em 22.08.2007

Última versão recebida em 10.08.2008

Aprovação em 18.08.2008

\footnotetext{
INTRODUCTION

Photorefractive keratectomy (PRK) and laser in situ keratomileusis (LASIK) are the most common surgeries performed for the treatment of refractive disorders. After these procedures, there is a corneal wound healing and stimulation of a fibrotic response, usually stronger with PRK than $\mathrm{LASIK}^{(1)}$, specially in the treatment for high myopia patients and may lead to haze development, compromising visual acuity and contrast sensitivity ${ }^{(2-3)}$.

The corneal epithelium removal induces a loss of keratocyte by apoptosis, migration of inflammatory cells and proliferation of keratocytes in the underlying stroma, followed by remodeling of collagen matrices ${ }^{(1,4)}$. It has been shown that corneal haze and keratocyte proliferation can be reduced by inhibiting the infiltration of inflammatory cells into the ablation area after $\mathrm{PRK}^{(5)}$.
} 
Mitomycin C (MMC) is a systemic chemotherapeutic drug derived from Streptomyces caespitosus, which suppresses the proliferation of rapidly growing cells by inhibiting DNA synthesis, secondary to alkylation ${ }^{(6)}$. MMC has been used with increasing frequency in eye surgery. It has improved the results of glaucoma surgery ${ }^{(7)}$, pterygium excision ${ }^{(8)}$, treatment of conjunctival and corneal intraepithelial neoplasia ${ }^{(9)}$ and refractive surgery ${ }^{(10)}$.

In PRK, MMC prevents corneal haze after treatment of high myopia, especially in patients whose corneal thicknesses are inadequate for laser in situ keratomileusis ${ }^{(10)}$. The effect of MMC on wound healing has been documented by inhibiting keratocyte proliferation, and activation, and consequently blockage of myofibroblast differentiation ${ }^{(1,11)}$. It is not clear, however, whether and how MMC affects inflammatory activities, such as infiltration of leukocytes and their actions. An inhibitory effect of MMC on leukocyte chemotaxis has been suggested in gastric cancer ${ }^{(12)}$, but no report seems to exist regarding ocular inflammation.

The purpose of this study was to evaluate the effects of MMC on the inflammatory response during the early stages of wound healing, using an epithelial scrape injury model of the mouse cornea.

\section{METHODS}

An experimental prospective study was performed on a mouse cornea in the research department of Ophthalmology at Columbia University. Twenty mice were used in this study.

\section{Animals}

Animal study adhered to the Association for Research in Vision and Ophthalmology Statement for the Use of Animals in Ophthalmic and Vision Research, and approved by the institutional animal care and use committee. The GFPU mice were obtained from the Jackson Laboratory (Bar Harbor, ME) and maintained in house. Only male mice were used in this study. Both eyes were used, a contralateral eye was used as the control to eliminate variations in inflammatory reactions among different animals. The injury was mild and the animals were never at risk of vision loss.

\section{Surgery}

The animals were anesthetized by an intraperitoneal injection of ketamine $(100 \mathrm{mg} / \mathrm{kg})$ and xylazine $(10 \mathrm{mg} / \mathrm{kg})$. The mechanical epithelial scrape injury was created after a circular mark using an about 1.2-mm diameter trephine. One filter paper ( $0.9 \mathrm{~mm}$ diameter) soaked with $20 \%$ ethanol was placed on the central cornea for one minute before performing a circular injury (1.2 mm diameter) in the center of the cornea (Figure 1). This injury was created with a blunt tip of a \#12 blade under a dissection microscope. Both eyes were used; the right eye received $0.02 \% \mathrm{MMC}$ for one minute, whereas the left eye received physiological saline after the scrape injury. Both eyes

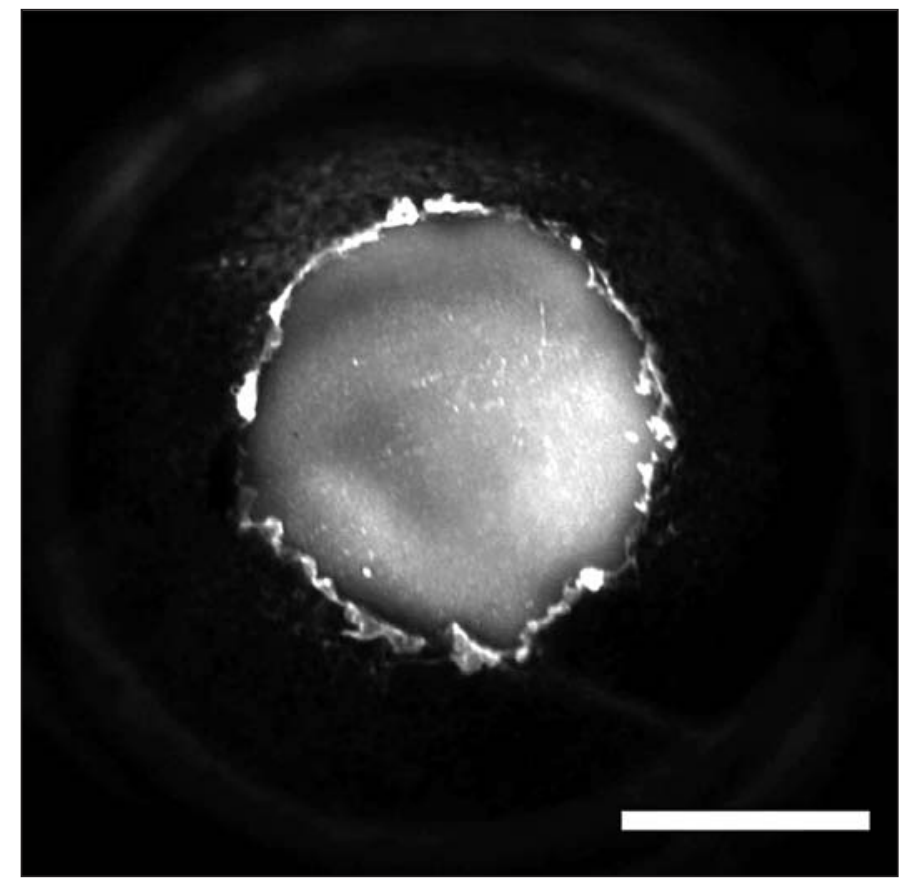

Figure 1 - Appearance of epithelial scrape injury in the cornea in a live mouse. Denuded area was stained with a drop of sulforhodamine 101 in saline, while areas of intact epithelium were protected from the dye. Bar, $1 \mathrm{~mm}$.

were irrigated extensively with balanced salt solution, and received erythromycin ointment.

\section{Histology}

Animals were sacrificed by intraperitoneal injection of pentobarbital $(100 \mathrm{mg} / \mathrm{kg}$ ) on days $1,2,5$, and 14 after surgery, and corneal whole mounts were prepared after fixation in $95 \%$ methanol. The epithelium was removed from a whole mount, which was then stained with hematoxylin and air-dried to prepare a flat specimen. To quantify the infiltration of polymorphonuclear leukocytes (PMNs), the total number of stromal PMNs was determined in a rectangular area of $350 \times 4500 \mu \mathrm{m}$ in the middle of the specimen in a digitized microscope image by displaying a magnified image on a computer monitor and identifying individual PMNs based on their horseshoe-shaped nuclear profile (Figure 2). The counting was done as a single blind test, the examiner counted blind samples. Cell division in the corneal stroma was determined by immunohistochemical detection of nuclear bromodeoxyuridine (BrdU) after intraperitoneal injection of BrdU 2 hours before sacrificing the mouse. PMNs in the tears were determined by collecting the tears at 24 hours and 48 hours after the epithelial scrape injury. For this, the mouse was anesthetized with ketamine and xylazine and $1 \mu \mathrm{l}$ of PBS was instilled into the eye, followed by collection of the fluid with a $1-\mu$ l glass pipette. The tear fluid was then applied to a glass slide, air dried, and stained with LeukoStat (Fisher Scientific, Pittsburgh, PA). Blood smear was used as a positive control. 


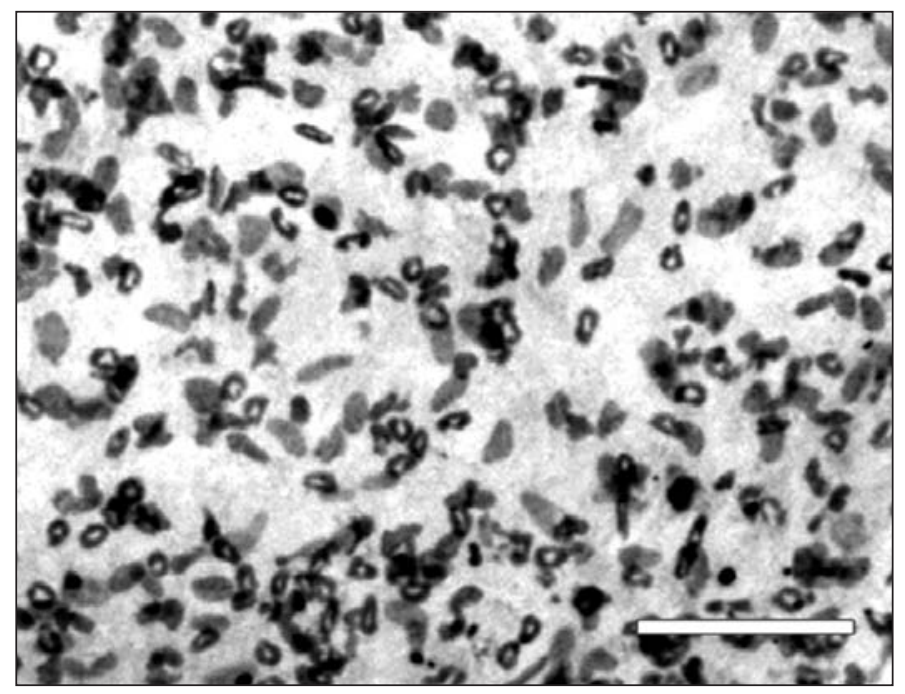

Figure 2 - PMNs were identified and differentiated from keratocytes by their unique donut-shaped nuclei in the corneal stroma. Bar, $100 \mu \mathrm{m}$.

\section{Statistical analyses}

The unpaired t-test was used to compare the number of PMNs in MMC eyes and control eyes. Statistical significance was accepted at a $\mathrm{P}<0.05$ level.

\section{RESULTS}

\section{Stroma cell division}

BrdU labeling demonstrated that stroma cell division was apparent in the injury area at 5 days but not at 2 days. This keratocyte division at 5 days was nearly completely inhibited by the MMC treatment, demonstrating the effectiveness of MMC treatment (Figure 3).

\section{Leukocytes in the tears}

No PMNs were found in the tears 24 and 48 hours after the injury.

\section{PMN infiltration}

Epithelial scrape injury triggered infiltration of PMNs into the corneal stroma. The PMNs accumulated into the anterior stroma of the injury site within 24 hours (Figure 4), by which time the epithelial opening was closed $80-100 \%$. At this time point, keratocytes were absent in the anterior stroma beneath the epithelial injury where PMNs accumulated. Most of the PMNs disappeared from the cornea by five days after the trauma. At two weeks, the level of PMNs was nearly identical to that of the untouched cornea. A comparison of corneas treated with saline and MMC revealed that there was no significant difference in the numbers of PMNs in these corneas at examined all time points $(\mathrm{P}>0.05)$ (Table 1).

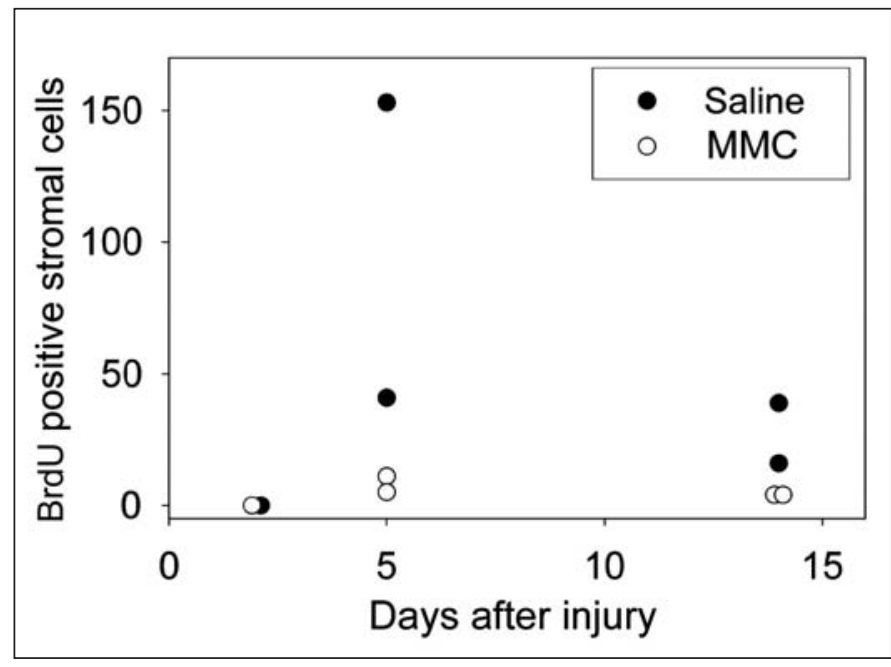

Figure 3 - Effect of MMC on keratocyte proliferation after epithelial scrape injury. Keratocyte proliferation was determined by BrdU incorporation.

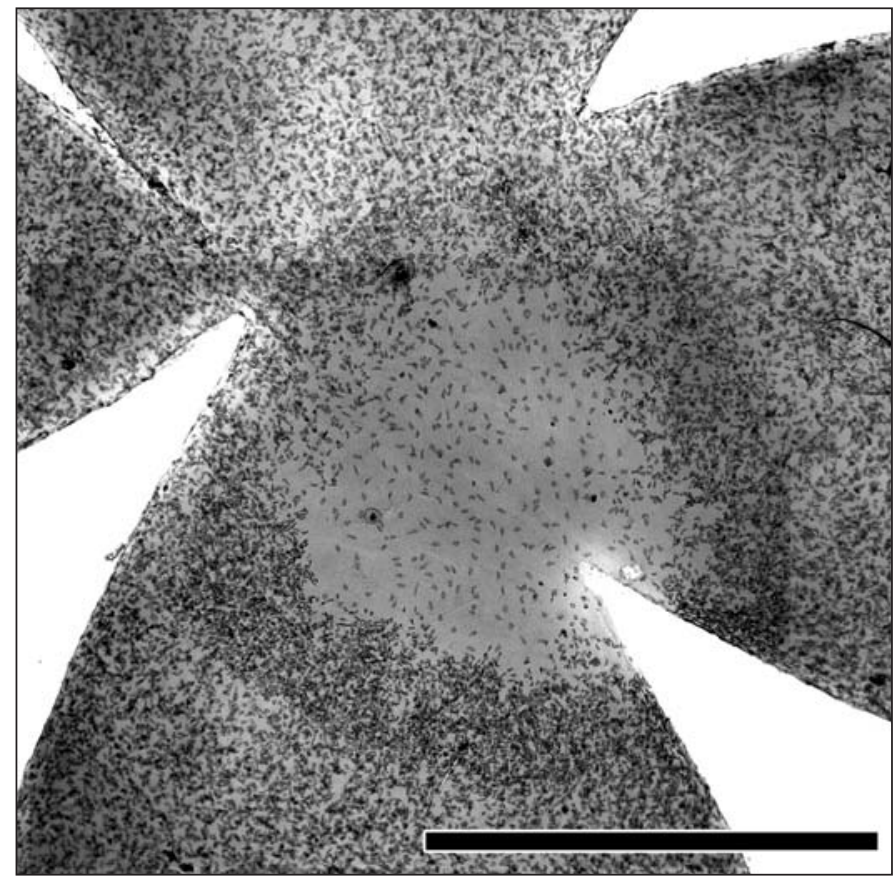

Figure 4 - PMN distribution in the MMC treated cornea at 24 hours after epithelial scrape. Bar, $1 \mathrm{~mm}$.

\begin{tabular}{|c|c|c|c|}
\hline $\begin{array}{l}\text { Time } \\
\text { point }\end{array}$ & $\begin{array}{c}\text { PMN MD } \pm \text { SD } \\
\text { MMC }\end{array}$ & $\begin{array}{l}\text { PMN MD } \pm \text { SD } \\
\text { Control }\end{array}$ & t-test \\
\hline $24 \mathrm{~h}$ & $1215.50 \pm 238.29$ & $1094.00 \pm 63.64$ & 0.6706 \\
\hline $48 \mathrm{~h}$ & $174.67 \pm 34.79$ & $187.67 \pm 72.01$ & 0.6386 \\
\hline $5 d$ & $55.00 \pm 7.07$ & $44.50 \pm 7.78$ & 0.5000 \\
\hline $14 d$ & $3.50 \pm 0.71$ & $3.00 \pm 1.41$ & 0.7952 \\
\hline
\end{tabular}




\section{DISCUSSION}

The cornea wound healing cascade is complex and mediated by cytokines, growth factors and chemokines ${ }^{(13-14)}$. PMNs are the first cells that migrate into tissues in response to insults ${ }^{(15)}$. It has been shown that the presence of leukocytes stimulates the epithelial healing to some extent after alkali injury $^{(16)}$. The early presence of leukocytes may act via cytokines to initiate migration of keratocytes. Proliferation may likewise be influenced by leukocytes from the limbal side ${ }^{(17)}$. Previous studies have been performed to block the infiltration of PMNs in the wound healing ${ }^{(18)}$, but long-term clinical impact has not been determined.

PRK and LASIK are the most common refractive surgeries performed for the correction of myopia, hyperopia and astigmatism. Clinical outcomes with these procedures are in large part dependent on the cornea wound healing response. Corneal haze is more common after PRK than after LASIK, because the corneal wound healing response and the stimulus for the fibrotic response are stronger ${ }^{(1)}$.

Many substances have been used to prevent haze formation in PRK: amniotic membrane, vitamins A and E, collagenase inhibitors, and ubiquinone Q10 ${ }^{(19-22)}$, but no controlled clinical trials have been reported, except for mitomi$\operatorname{cin} \mathrm{C}^{(23)}$.

MMC is a drug that has been used frequently to reduce haze formation owing, presumably, to its inhibition of proliferation of activated keratocytes ${ }^{(1)}$. Despite the importance of PMNs in wound healing and the prevalence of MMC use in corneal surgery, effects of MMC on PMNs have not been reported, to the best of our knowledge. MMC has been reported to decrease the chemotaxis of PMNs in patients with gastric cancer ${ }^{(12)}$, but its relevance to the corneal wound healing is not clear. This study with mouse eyes showed that MMC has no measurable effect in the migration of PMNs during early stages of corneal wound healing. This supports the idea that MMC effect on haze reduction is solely due to its inhibition of keratocytes, and not PMNs. Perhaps this is so because MMC action is short-lived and no longer effective by the time PMNs appear in the cornea after injury, and thus MMC has no effect on PMN activities. Since the study addressed only the movement of PMNs, it will be important to investigate other activities of PMNs such as a release of oxidative enzymes and agents and also their phagocytic activity. This will ensure that side effects of MMC are fully understood when used in corneal surgery.

\section{CONCLUSION}

MMC at $0.02 \%$ for one minute has no measurable effect on appearance, migration, and disappearance of corneal PMNs during early stages of corneal wound healing after epithelial scrape injury in the mouse eye model.

\section{RESUMO}

Objetivo: O objetivo do estudo foi determinar se a mitomicina $\mathrm{C}$ (MMC) altera o aparecimento dos leucócitos polimorfonucleares (PMN) no estroma corneano após abrasão epitelial central, utilizando olhos de camundongo como modelo. Métodos: Vinte camundongos foram submetidos à abrasão epitelial em córnea central utilizando etanol a $20 \%$. Após a lesão, o olho direito recebeu MMC a $0,02 \%$ por 1 minuto, enquanto o olho esquerdo recebeu solução salina. Os animais foram sacrificados em 1, 2, 5 e 14 dias após a cirurgia e a córnea foi preparada para histologia. A distribuição dos PMN foi analisada e digitalizada em imagens microscópicas. A divisão celular na córnea foi detectada pela imuno-histoquímica da bromodeoxirudina (BrdU), injetada intraperitonialmente duas horas antes dos animais serem secrificados. Resultados: A lesão epitelial gerou infiltração de PMN no estroma da córnea. A análise da distribuição dos PMNs revelou que não houve diferença estatisticamente significante entre os olhos tratados e não tratados com MMC, em todos os tempos estudados. O estudo com BrdU mostrou que a MMC quando utilizada a $0,02 \%$ por um minuto bloqueou completamente a proliferação de ceratócitos. Conclusão: O tratamento com MMC, que é utilizada comumente na prática clínica, inibe a proliferação dos ceratócitos durante a cicatrização corneana, porém quando utilizada a $0,02 \%$ por um minuto, não altera a infiltração dos PMNs dentro do estroma corneano após lesão epitelial em córneas de camundongos.

Descritores: Mitomicina C/uso terapêutico; Mitomicina C/ administração \& dosagem; Leucócito; Córnea; Ceratomileuse assistida por excimer laser in situ; Ceratectomia fotorrefrativa; Modelos animais

\section{REFERENCES}

1. Netto MV, Mohan RR, Ambrósio R Jr, Hutcheon AE, Zieske JD, Wilson SE. Wound healing in the cornea: a review of refractive surgery complications and new prospects for therapy. Cornea. 2005;24(5):509-22.

2. Amm M, Wertzel W, Winter M, Uthoff D, Duncker GI. Histopathological comparison of photorefractive keratectomy and laser in situ keratomileusis in rabbits. J Refract Surg. 1996;12(7):758-66.

3. Wachtlin J, Laugenbeck K, Schründer S, Zhang EP, Hoffmann F. Immunohistology of corneal wound healing after photorefractive keratectomy and laser in situ keratomileusis. wachtlin@ukbf.fu-berlin.de. J Refract Surg. 1999;15(4):451-8.

4. Kuo IC. Corneal wound healing. Curr Opin Ophthalmol. 2004;15(4):311-5. Review.

5. Choi YS, Kim JY, Wee WR, Lee JH. Effect of the application of human amniotic membrane on rabbit corneal wound healing after excimer laser photorefractive keratectomy. Cornea. 1998;17(4):389-95.

6. Calabresi P, Chabner BA. Antineoplastic agents. In: Goodman LS, Gilman A, Gilman AG, editors. Pharmacological basis of therapeutics. $8^{\text {th }}$ ed. New York: Pergamon Press; c1990. p.1247-8.

7. Maquet JA, Dios E, Aragón J, Bailez C, Ussa F, Laguna N. Protocol for mitomycin C use in glaucoma surgery. Acta Ophthalmol Scand. 2005;83(2): 196-200.

8. Levy RL, Naidu S, Jacobson L. Safety and efficacy of the technique of complete tenon's membrane excision and mitomycin $\mathrm{C}$ in pterygium surgery. Eye Contact Lens. 2005;31(3):105-8. 
9. Prabhasawat $\mathrm{P}$, Tarinvorakup $\mathrm{P}$, Tesavibul N, Uiprasertkul M, Kosrirukvongs $\mathrm{P}$, Booranapong W, Srivannaboon S. Topical $0.002 \%$ mitomycin C for the treatment of conjunctival-corneal intraepithelial neoplasia and squamous cell carcinoma. Cornea. 2005;24(4):443-8.

10. Hashemi H, Taheri SM, Fotouhi A, Kheiltash A. Evaluation of the prophylactic use of mitomycin-C to inhibit haze formation after photorefractive keratectomy in high myopia: prospective clinical study. BMC Ophthalmol. 2004;4:12.

11. Xu H, Liu S, Xia X, Huang P, Wang P, Wu X. Mitomycin C reduces haze formation in rabbits after excimer laser photorefractive keratectomy. J Refract Surg. 2001;17(3):342-9.

12. Hirano T. Changes in polymorphonuclear leukocyte motility under agarose and luminol-dependent chemiluminescence response in patients with gastric cancer. Gastroenterol Jpn. 1984;19(5):447-56.

13. Tuli S, Goldstein M, Schultz GS. Modulation of corneal wound healing. In: Krachmer JH, Mannis MJ, Holland EJ, editors. Cornea. $2^{\text {nd }}$ ed. Philadelphia: Elsevier Mosby; 2005. p.133-50.

14. Wilson SE, Liu JJ, Mohan RR. Stromal-epithelial interactions in the cornea. Prog Retin Eye Res. 1999;18(3):293-309. Review.

15. Hong JW, Liu JJ, Lee JS, Mohan RR, Mohan RR, Woods DJ, et al. Proinflammatory chemokine induction in keratocytes and inflammatory cell infiltration into the cornea. Invest Ophthalmol Vis Sci. 2001;42(12):2795-803

16. Gan L, Fagerholm P, Kim HJ. Effect of leukocytes on corneal cellular proliferation and wound healing. Invest Ophthalmol Vis Sci. 1999;40(3):575-81.
17. Gan L, Hamberg-Nyström H, Fagerholm P, Van Setten G. Cellular proliferation and leukocyte infiltration in the rabbit cornea after photorefractive keratectomy. Acta Ophthalmol Scand. 2001;79(5):488-92

18. Bilgihan A, Bilgihan K, Yis O, Sezer C, Akyol G, Hasanreisoglu B. Effects of topical vitamin $\mathrm{E}$ on corneal superoxide dismutase, glutathione peroxidase activities and polymorphonuclear leucocyte infiltration after photorefractive keratectomy. Acta Ophthalmol Scand. 2003;81(2):177-80.

19. Brancato R, Schiavone N, Siano S, Lapucci A, Papucci L, Donnini M, et al Prevention of corneal keratocyte apoptosis after argon fluoride excimer laser irradiation with the free radical scavenger ubiquinone Q10. Eur J Ophthalmol. 2000;10(1):32-8.

20. Wang MX, Gray TB, Park WC, Prabhasawat P, Culbertson W, Forster R, et al. Reduction in corneal haze and apoptosis by amniotic membrane matrix in excimer laser photoablation in rabbits. J Cataract Refract Surg. 2001;27(2):310-9.

21. Vetrugno M, Maino A, Cardia G, Quaranta GM, Cardia L. A randomised, double masked, clinical trial of high dose vitamin A and vitamin E supplementation after photorefractive keratectomy. Br J Ophthalmol. 2001;85(5):537-9.

22. Corbett MC, O'Brart DP, Patmore AL, Marshall J. Effect of collagenase inhibitors on corneal haze after PRK. Exp Eye Res. 2001;72(3):253-9.

23. Bedei A, Marabotti A, Giannecchini I, Ferretti C, Montagnani M, Martinucci C, Barabesi L. Photorefractive keratectomy in high myopic defects with or without intraoperative mitomycin C: 1-year results. Eur J Ophthalmol. 2006; $16(2): 229-34$ 